\title{
Development and Validation of a Model Predicting Students' Sense of School Belonging and Engagement as a Function of School Climate
}

\author{
Jérôme St-Amand \\ Université du Québec en Outaouais, Gatineau, Canada \\ https://orcid.org/0000-0003-3006-6716 \\ Jonathan Smith \\ Université de Sherbrooke, Sherbrooke, Canada \\ https://orcid.org/0000-0002-6451-783X \\ Aziz Rasmy \\ University Hassan II of Casablanca, Casablanca, Morroco \\ https://orcid.org/0000-0002-8052-1636
}

\begin{abstract}
For many years, studies have explored the relationship between school belonging and engagement, two concepts that are associated with several positive outcomes. However, the relative influence that school climate may have on these components has received little attention. Based on the theoretical perspective of Janosz et al (1998), school belonging and engagement were examined as a function of multiple dimensions of school climate, and were tested across genders. The research took place in Morocco, and participants were 238 students from 9th grade (101 males, 137 females; Mage $=15.1$ ) living in the cities of Casablanca and Témara. Students completed a questionnaire aimed at measuring school belonging, school engagement, and school climate. Correlational and structural equation modeling methods were used to analyze the aforementioned relationships. Results showed that only the climate of justice had a positive effect on school belonging, which, in turn, had a positive effect on the three types of school engagement. The multigroup analysis revealed the relation between school belonging and behavioral engagement to be partially invariant across genders. These results highlight the benefits of creating a positive school climate which can support students' belonging and engagement.
\end{abstract}

Keywords: empirical validation; theoretical model; sense of belonging; school engagement; school climate 


\section{Introduction}

Since the end of the 1980s, researchers have considered that feeling a low sense of belonging to school is a factor that explains school disengagement to the point of causing school dropout (Faircloth \& Hamm, 2005; Finn, 1989; Goodenow \& Grady, 1993; Korpershoek, al., 2020; Smith et al., 2020; St-Amand et al., 2020b). Furrer and Skinner (2006) cited that when the feeling of belonging is low, a number of negative consequences can lead young people to withdraw from school and, ultimately, drop out: "[...] children who feel unconnected to key social partners should find it harder to become constructively involved in academic activities; should more easily become bored, worried, and frustrated; and should be more likely to become disaffected" (p. 149). On the other hand, a strong feeling of belonging to school is a concept underlying students' motivation to learn (Gillen-O'Neel \& Fuligni, 2013; St-Amand et al., 2020a), which accounts for school perseverance (St-Amand et al., 2020b), psychological well-being (Korpershoek, et al., 2020), or prosocial behaviors (Demanet \& Van Houtte, 2012). In recent years, girls, compared to boys, have tended to favor the pursuit of studies more by demonstrating better academic performance, engaging more in school tasks, and feeling a stronger sense of belonging to school (Allen et al., 2018; Kuang et al., 2019). Osterman (2000) concluded her article by raising the importance of developing the feeling of belonging to school, a psychological phenomenon present in all students: "[...] from a review of even these limited sources it is possible to conclude that belongingness is an extremely important concept. As a psychological phenomenon, it has farreaching impact on human motivation and behavior" (p. 359). However, the effect of different types of school climates on students' school belonging and their school engagement is less well documented. The objective of this article is to measure the effect of three school climates (justice, relational, safety) on students' school belonging and school engagement, and to test the invariance of these relationships across genders. We first present the literature review followed by our theoretical research hypotheses. This will be followed by the methodology, results, discussion, and conclusion of the article.

\section{Literature Review}

The sense of belonging is a concept which, by its name, can be confusing. Authors used different terms to designate it, such as "school membership", "school belonging", "school connectedness", "sense of school membership", and "youth connectedness" (Booker, 2007; Crooks et al., 2007; Goodenow, 1993a, 1993b; Hagborg, 1998; Isakson \& Jarvis, 1999; Lewis et al., 2006; McGraw et al., 2008; St-Amand et al., 2017a, 2017b; Uwah et al., 2008). For the past many years, several definitions of school belonging have been proposed by the scientific community in educational sciences (Allen et al., 2018; Deci et al., 1991; Goodenow 1993a; Janosz et al., 1998; Langevin, 1999; St-Amand et al., 2017a, 2017b; Wehlage et al., 1989; Williams \& Downing, 1998). In the light of these definitions, researchers attempted to identify the dimensions of this concept. Using the methodology of Walker and Avant (2011), St-Amand et al. (2017a) identified four definitional attributes: students must (1) feel a positive emotion towards school; (2) maintain positive social relationships with their peers and teachers; (3) perceive a synergy (harmonization) and a certain similarity with the 
members of the group; and (4) become actively involved in the school environment. The identification of these attributes gave rise to a definition that is increasingly used in the scientific community:

"School belonging is a complex and multidimensional concept that includes an emotional, social, participatory, and adaptive dimension. In this context, the sense of school belonging is achieved when students develop positive social relationships with members of the school environment; social relationships are characterized by encouragement, valorization, acceptance, support, respect, and friendship. Belonging also refers to positive emotions, which could be described as emotional attachments, more precisely to a feeling of intimacy, feeling part of a supportive environment, and a sense of pride in the school. The sense of belonging is characterized by active participation in school activities (e.g., extracurricular activities) and teacher-led activities in the classroom, as well as the adoption of norms, standards, and values conveyed within the socio-educational environment. This feeling refers to the harmonization of the needs and desires of the student to those of the members of the group, an element reflecting the positive adjustment to the school environment" (loose translation) (St-Amand et al., 2017a, p. 14).

To a certain extent, this definition refers to the work of Goodenow (1993b) who argued that the feeling of belonging in a school environment refers to a feeling of acceptance, worth, inclusion, encouragement, and harmony within the group. This concept involves notions such as support, respect, and autonomy: "a student's sense of being accepted, valued, included, and encouraged by other (teachers and peers) in the academic classroom setting and of feeling oneself to be an important part of the life and activity of the class. More than simple perceived liking or warmth, it also involves support and respect for personal autonomy and for the student as an individual" (Goodenow, 1993a, 1993b) (p. 80).

There are many determinants of the sense of school belonging (Ahmadi, et al., 2020; Allen et al., 2018; Janosz et al., 1998; Slaten et al., 2016). Allen et al. (2018) categorized the determinants of the sense of school belonging into factors at the individual level (e.g., personality, self-esteem, social skills, motivation, optimism), factors at the micro level (e.g., social relationships, parents, peers, teacher support, presence of friends), and the meso-level factors (e.g., extracurricular activities, discipline in the classroom, the climate of justice, the climate of security). In a systemic model of the socio-educational environment where school belonging is a central component, Janosz et al. (1998) also suggested, among other things, that the feeling of school belonging is built and structured through the climate of security, the climate of justice, and the relational climate.

\subsection{The climates contributing to school belonging}

\subsubsection{The relational climate}

Theorists suggested that the quality of social relationships contributes directly and positively to developing students' sense of school belonging. However, 
several types of relationships can be considered, including friendships, dyadic relationships, teacher/students' relations, peer relations, social processes present in class, or peer acceptance (Dimitrellou \& Hurry, 2019; Juvonen, 2006; Ibrahim and El Zaatari, 2020). Within these different types of relationships, the quality of social bonds must be present, and acceptance must prevail over social isolation. As an element negatively influencing school belonging, the concept of social isolation refers precisely to the need for students to interact frequently with their peers (Dimitrellou \& Hurry, 2019; London and Ingram, 2018; Wehlage et al., 1989). However, in order to foster quality social relations, teachers obviously have a role to play. Creemers and Kyriakides (2008) proposed in this regard an integrating model specifically highlighting that the quality of social relations depends on the work of teachers, that is to say on everything that can be put in place to promote a good social climate within the classroom. Like Juvonen (2006), other theorists also argued that the quality of social relations between teachers and students directly influences young people's sense of belonging (StAmand, 2018; Newmann et al., 1992; Roeser et al., 1996; Wehlage et al., 1989). Still, according to Juvonen (2006): “[...] Students are presumed to comply and be motivated to learn when they feel supported and respected by their teachers" ( $p$. 658).

\subsubsection{The climate of justice}

Among other things, adolescents assess their school environment through the treatment they receive from their teachers (Peter \& Dalbert, 2010). This experience of justice is important for adolescents because it shapes their world views and the 'social map' they construct in their mind (Resh \& Sabbagh, 2014, p. 317). Being respected and treated fairly are elements that contribute to student appreciation of their school environment and to the development of their feeling of school belonging (Molinari et al., 2013). This perspective is also true in the workplace where employees report that being treated fairly contributes to their sense of belonging in their work environment (Tyler \& Blader, 2000). In recent years, the link between the climate of justice and students' sense of belonging to school has been theoretically underlined by a certain number of theorists (Janosz et al., 1998; Molinari et al., 2013; Newmann et al., 1992). Empirical studies showed that the climate of justice has an effect on school belonging. More specifically, Resh and Sabbagh (2014) showed that the interactional climate of justice contributes to the feeling of belonging but that the climate of justice with regard to school results does not. In the same vein, Molinari et al. (2013) underlined the effect of the interactional climate of justice on the feeling of belonging. An interactional climate of justice refers to perceptions of fairness in the interpersonal treatment received by students from their teachers (Berti et al., 2010).

\subsubsection{The climate of security}

The link between the climate of security and the feeling of belonging has been established for many decades on a theoretical level (Janosz et al., 1998; Maslow, 1970, 1962). Maslow (1970) suggested five essential needs that are important to meet in order to fulfill oneself as an individual: physiological needs (eating, drinking, breathing, sleeping); security needs (stability, protection, structure, order, laws); belonging and emotional needs (love, friendship, intimacy, family, 
children); self-esteem (development of skills, success, trust in others, independence, freedom); and personal fulfillment (moral, creativity, problem solving, exploitation of talents, capacities, potentials). When physical and security needs are met, an individual naturally seeks to develop a sense of belonging; it is at this stage that a person keenly feels the absence of friends, children, or a spouse. In this regard, Baumeister and Leary (1995, p. 497) indicated that "belongingness needs do not emerge until food, hunger, safety, and other basic needs are satisfied". Beyond these basic needs, the climate of security relates to the feeling of security in social relationships with parents, friends, or teachers (Osterman, 2000). Peers are also those who can provide that feeling of security both at school and during weekends. This implies physical and emotional security in a context where threats are absent and peer support is present. The notion of security also implies the feeling of trust, the possibility of being able to open up to others (Einberg et al., 2015), and the preservation of this feeling of intimacy between members of the group (McMillan \& Chavis, 1986). This feeling of security ultimately allows students to feel a strong sense of school belonging (van Gijn-Grosvenor \& Huisman, 2020).

\subsection{School belonging and school engagement}

Over the past decades, theoretical work showed a link between school belonging and academic engagement. In a sequential model, Connell et al. (1994) suggested a direct link between school belonging (and a sense of competence) and school engagement, which in turn influences academic achievement. Newmann et al. (1992) developed a model establishing the link between school belonging and school engagement, specifying that this feeling positively and directly influences school engagement. Other theoretical models also raised the importance of this close relationship between school belonging and school engagement (Finn, 1989; St-Amand et al., 2020a; Wehlage et al., 1989). St-Amand et al. (2020b) validated a model with a sample high school student suggesting a link between school belonging and the three forms of school engagement: in this case, cognitive, behavioral, and affective engagement. Finn (1989) for his part developed a dynamic model illustrating the relationship between school belonging and school engagement. This model is based on the perspective that participation in activities is fundamental to school success which, in turn, fosters a sense of belonging to school. Many other researchers suggested that school belonging constitutes the basis of school engagement (Korpershoek et al., 2020; Singh et al., 2010, 2008). Wehlage et al. (1989) emphasized the quality of teaching practices and the ability of the school to promote the importance of education. From this theoretical perspective, the relationship between school belonging and school engagement is bidirectional in nature, which differs from previous models where school belonging is more of a determinant of school engagement (Wehlage et al., 1989).

\subsection{Theoretical perspective of this study}

In recent years, theoretical work has determined that the climates that prevail in school (security, justice, and relational) contribute to the development of a strong sense of school belonging (Allen et al., 2018; Janosz et al., 1998; Juvonen, 2006; Newmann et al., 1992). From a systemic perspective, Janosz et al. (1998) developed a model of the socio-educational environment where climates (e.g., 
security, relational, justice) tend to directly contribute to developing students' sense of belonging to school. In turn, school belonging affects school engagement (e.g., cognitive, behavioral, and affective engagement). This theoretical line therefore implies that school belonging mediates the relationship between the dimensions of the school climate (e.g., security, relational, justice) and student behavior (school engagement). However, this has never been empirically validated. In this model, school belonging plays an essential role because it transcends all of these school climates, such as when pupils have:

" "[...] the impression that their environment is meaningful, that it promotes human contact, that it ensures their protection and that it guarantees the recognition of their rights and their efforts in the same way that it sanctions in a fair and equitable way their transgressions of the norm, they develop a feeling of belonging" (loose translation) (Janosz et al., 1998, p. 294).

The present study therefore aims to explain the emergence of school engagement (behavioral, cognitive, and affective) from school belonging and the different types of school climates (e.g., security, relational, justice), and to test for invariance across genders. Derived from the work of Janosz et al. (1998), Figure 1 illustrates the determinants of school engagement from the different groups of predictor variables; one of these groups (school belonging) is directly linked with the different forms of school engagement while other variables (the different school climates) indicate indirect links with school engagement.

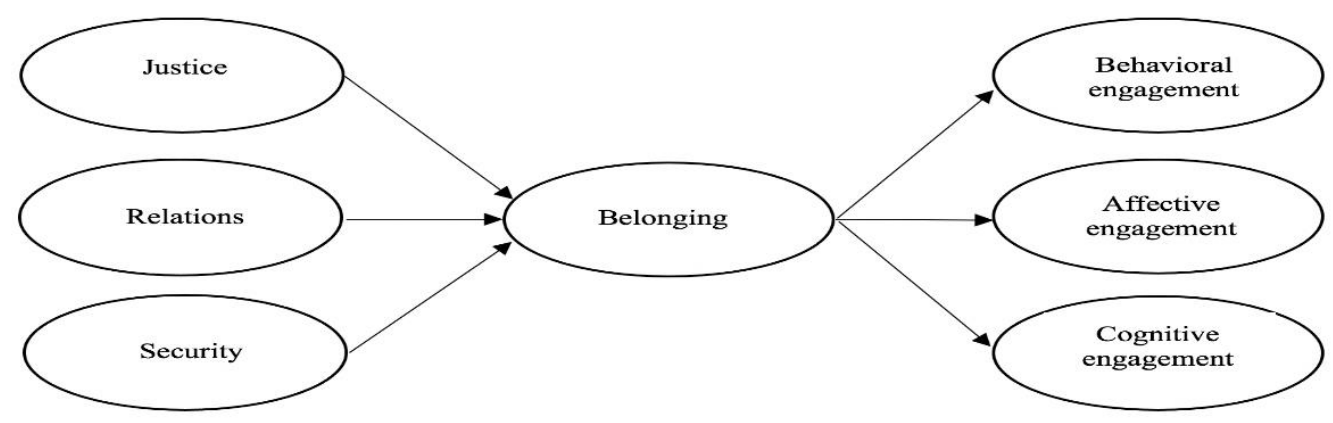

Figure 1: Initial model

Model inspired by the work of Janosz et al. (1998) describing the links between school climates, school belonging, and school engagement.

The organization of these relationships within the model leads us to formulate four research hypotheses:

H1: The different types of school climates (security, relational, justice) have a positive effect on school belonging.

H2: School belonging has a positive effect on the three types of school engagement (cognitive, affective, and behavioral).

H3: The different types of school climates (security, relational, justice) affect the three types of school engagement (cognitive, affective, and behavioral) indirectly through school belonging. 
H4: The positive effect of school belonging on the three types of school engagement (cognitive, affective, and behavioral) is stronger for females than for males.

\section{Methodology}

\subsection{Design and sample}

Participants were recruited by convenience sampling because they were readily available and easy to get in contact with. More precisely, our sample included a total of $2389^{\text {th }}$ grade students, 101 boys and 137 girls, aged between 15 to 16 $\left(M_{\text {age }}=15.1\right)$ from two secondary schools located in the cities of Casablanca and Témara in Morocco. The data collection took place during the months of March and April 2019. A trained assistant visited the school during regular class time and administered the questionnaire. Students were instructed to respond to all questions and to keep their answers confidential. It took less than 20 minutes to complete the questionnaire. The questionnaire was comprised of 26 items that we translated into Arabic, allowing for the measure of seven different constructs. Participants had to indicate their level of agreement regarding each item on a Likert scale.

To measure the variables in this study and the quality of certain characteristics of the school environment, the authors used only part of the Questionnaire sur l'environnement socioéducatif (QES-secondaire) [Questionnaire on the socioeducational environment (QES-high school)], namely school belonging, school climates, and the different types of school engagement (Janosz \& Bouthillier, 2007).

\subsection{Measures}

\subsubsection{School belonging}

To measure school belonging, we used a five-item subscale that assessed students' sense of school belonging to the school community (items: "I feel proud to be a student at my school", "I feel like I'm really part of my school", "The other students at this school take my opinions seriously", "Sometimes I feel as if I don't belong here", and "I wish I were in a different school") (Janosz \& Bouthillier, 2007). The last two items were reverse coded, and item scores were averaged to generate a score reflecting school belonging $(M=3.91, S D=.98, a=.90)$.

\subsubsection{School engagement}

Self-reported items were used to measure school engagement. These items represent three dimensions converging towards a more global concept measuring school engagement. In this study, the authors consider each of these three dimensions in a unique way, as suggested by most scholars in the field of school motivation (Fredricks et al., 2004). First, behavioral engagement measures positive behaviors such as the following of classroom rules and adherence to classroom norms, as well as the absence of disturbing behaviors (Fredricks et al., 2004). To measure behavioral engagement, participants responded to the fouritem subscale that assessed this dimension (Janosz \& Bouthillier, 2007) (items: "In the past 12 months, have you missed school without a valid excuse?", "In the past 12 months, have you missed a class while you were in school?", 'In the past 12 months, have you disturbed your class on purpose?", and "In the past 12 months, have you 
responded to a teacher by being unpolite?") $(M=2.27, S D=1.45, a=.77)$. Second, affective engagement in school tasks refers to feelings, interest, perceptions, and attitudes towards school (Fredricks et al., 2004). To measure affective engagement, participants responded to the five-item subscale that assessed this dimension (Janosz \& Bouthillier, 2007) (items: "I like school", "I have fun at school", "What we learn in class is interesting", "I am very enthusiastic when the job to be done is quite difficult", and "Often I don't feel like stopping work at the end of a course") (M $=4.59, S D=1.18, a=.75)$. Third, the cognitive dimension of school engagement relates to the psychological investment in learning school subjects (Fredricks et al., 2004). To measure cognitive engagement, participants responded to the three-item subscale that assessed this dimension (Janosz \& Bouthillier, 2007) (items: "I willing to make efforts in mathematics?", "I am willing to devote time to mathematics?", and "I want to learn more about what we do in mathematics") ( $M=$ $5.30, S D=1.49, a=.75)$.

\subsubsection{School climates}

The climate of security refers to the respondent's perception of the safety of the students, of the order and tranquility of the environment, as well as the perceived risks of their victimization (Janosz \& Bouthillier, 2007). To measure the climate of security, participants responded to the four-item subscale that assessed this variable (Janosz \& Bouthillier, 2007) (items: "There are risks of being assaulted in this school", "We are easily intimidated (threatened, harassed, etc.) in this school", "There are places in the school where the students are afraid to go", and "In this school, many students are afraid of other students") $(M=3.23, S D=1.23, a=.87)$.

The climate of justice refers to the perceived fairness in the (disciplinary) supervision system and to the way students are treated at school. This climate also refers to the recognition of the legitimacy and fairness of the rules, judicious application of fair school rules or assessments, and the feeling that the merit or punishment goes to the behavior rather than to the students themselves (Janosz \& Bouthillier, 2007). To measure the climate of justice, participants responded to the four-item subscale that assessed this variable (Janosz \& Bouthillier, 2007) (items: "The rules of this school are fair", "The punishments at this school are fair", and "In this school, students are treated fairly") $(M=3.70, S D=1.47, a=.79)$. The relational climate refers to the atmosphere that reigns in the relationships between students in the respect they show and the warmth of their interactions. It is indicative of the quality of social relations between them (Janosz \& Bouthillier, 2007). To measure the relational climate, participants responded to the three-item subscale that assessed this variable (Janosz \& Bouthillier, 2007) (items: "Students can rely on each other", "Relations between students are warm and friendly", and "In general, the students get along well with each other") $(M=4.37, S D$ $=1.08, a=.89$ ).

\subsection{Analytical strategies}

\subsubsection{Preliminary analyses}

First, preliminary analyses indicated an acceptable distribution of the data, homogeneity of variance, and the absence of multicollinearity. Following initial data processing and the removal of outliers, missing data was processed using a technique called maximum likelihood (EM or expectation maximization). Since 
there was a very low percentage of missing data (5\%), this technique correctly reflected the uncertainty of missing values and preserved important aspects of distributions, as well as important relationships between variables (Tabachnick \& Fidell, 2013).

\subsubsection{Main analyses}

Second, considering that the N:q ratio (5 observations -participants- for each estimated parameter) can be as low as 5 to 1 (Bentler \& Chou, 1987), structural equation modeling analyses (SEM) were carried out on the modeling presented previously (see Figure 1). To perform this type of analysis, a first hypothetical model is usually tested. To examine whether this model adequately fits the data, different fit indices are needed: chi-square ( $\chi 2)$, CFI, TLI, and RMSEA. As Hu and Bentler (1999) suggested, a good model should provide acceptable results on various fit tests. The global adjustment index used is $\chi^{2}$ (also called chi-square likelihood ratio or generalized likelihood ratio). A non-significant value at the $\chi^{2}$ index generally reflects a good fit (Tabachnick \& Fidell, 2013). Other indices have been used such as the CFI (comparative fit index) and the TLI (TuckerLewis index). Values greater than or close to 0.95 for these two indices indicate an appropriate fit of the data (Hu \& Bentler, 1999; Kline, 2016). The RMSEA (root mean square residual error of approximation) requires a value of 0.06 or less to be considered as an adequate data fit (MacCallum et al., 1996).

From the various adjustment indices obtained while testing the hypothetical model, the modification indices (Lagrange multiplier) were used to improve the adjustment of the model; in modifying the hypothetical model, we made sure to respect the logic and consistency of the underlying theory (Perry et al., 2015). The preferred estimation technique in this research is the maximum likelihood. Maximum likelihood is a commonly used estimation method for this type of analysis. According to Kline (2016), this method is unbiased in addition to being efficient and consistent.

In order to explore whether the relationships under study varied according to the gender of the students, we used a multigroup approach, as advocated by Byrne (2016) in a confirmatory approach to comparing models. This invariance procedure confirms the equality (or not) of the estimated parameters. To achieve this, we imposed equality constraints on the parameters of the models to check if the models are equivalent according to the gender of the students. These statistical procedures are clearly explained by Byrne (2016). Two indices are used to measure the invariance of the parameters: the chi-square difference and the CFI difference (Byrne, 2016). Since the use of both methods are still the subject of debates in the scientific community, and that "it is hoped that statisticians engaged in Monte Carlo simulation research related to structural equation modeling will develop more efficient and useful alternative approaches to this decision-making process in the near future" (Byrne, 2016, p. 307), we opted to report the $\mathrm{X}^{2}$-difference test knowing that more work needs to be conducted in this area (Byrne, 2016). To perform these statistical analyses, the SPSS-AMOS software (version 27) was used. 


\section{Results}

\subsection{Descriptive statistics}

Table 1 shows descriptive statistics for each variable that we included in the model and the correlations between them. Means varied from 2.27 (behavioral engagement) to 5.30 (cognitive engagement), and standard deviations varied from .87 (belonging) to 1.49 (cognitive engagement). All correlations were significant $(p<.01)$, except for the associations between the climate of justice and the climate of security $(-.07, p=.28)$, the climate of justice and the relational climate $(-.01, p=.99)$, the climate of justice and cognitive engagement $(.03, p=$ $.60)$, the climate of security and affective engagement $(-.04, p=.95)$, the relational climate and affective engagement $(.11, p=.95)$, the climate of security and behavioral engagement $(.03, p=.96)$, the relational climate and behavioral engagement $(-.04, p=.54)$, the climate of security and cognitive engagement ($.02, p=.78)$, the relational climate and cognitive engagement $(.07, p=.27)$, the relational climate and school belonging $(.12, p=.06)$, the relational climate and the climate of security $(-.06, p=.40)$, and the climate of security and school belonging $(-.04, p=.55)$. The significant correlations varied from weak $(.20, p<$ $.01)$ to strong $(.75, p<.01)$. Four variables displayed negative correlations with behavioral engagement: belonging $(-.37, p<.01)$, cognitive engagement $(-.28, p<$ $.01)$, affective engagement $(-.20, p<.01)$, and the climate of justice $(-.26, p<.01)$. Our results showed that all other correlations were positive.

Table 1: Descriptive statistics (means and SDs) and Pearson correlations among all study variables

\begin{tabular}{|c|c|c|c|c|c|c|c|}
\hline Variables & 1 & 2 & 3 & 4 & 5 & 6 & $\begin{array}{c}\mathrm{M} \\
\text { (SD) }\end{array}$ \\
\hline 1.Belonging & & & & & & & $\begin{array}{l}3.91 \\
(.87)\end{array}$ \\
\hline 2.Security & -.04 & & & & & & $\begin{array}{c}3.23 \\
(1.23)\end{array}$ \\
\hline 3.Relations & .12 & -.06 & & & & & $\begin{array}{l}4.37 \\
1.08\end{array}$ \\
\hline $\begin{array}{l}\text { 4.Cognitive } \\
\text { engagement }\end{array}$ & $.33^{* *}$ & -.02 & .07 & & & & $\begin{array}{c}5.30 \\
(1.49)\end{array}$ \\
\hline $\begin{array}{l}\text { 5.Behavioral } \\
\text { engagement }\end{array}$ & $-.37^{* *}$ & .03 & -.04 & $-.28^{* *}$ & & & $\begin{array}{c}2.27 \\
(1.45)\end{array}$ \\
\hline $\begin{array}{l}\text { 6.Affective } \\
\text { engagement }\end{array}$ & $.75^{* *}$ & -.04 & .11 & $.20^{* *}$ & $-.20^{* *}$ & & $\begin{array}{c}4.59 \\
(1.18)\end{array}$ \\
\hline 7.Justice & $.44^{\star *}$ & -.07 & -.01 & .03 & $-.26^{* *}$ & $.36^{* *}$ & $\begin{array}{c}3.70 \\
(1.47)\end{array}$ \\
\hline
\end{tabular}

Note. $N=238 .{ }^{*} p<.05,{ }^{* *} p<.01$ 


\subsection{Structural equation modeling}

4.2.1 Hypothetical model

In our Figure 2, we illustrate the basic hypothetical model for examining the relationships between our latent variables. More precisely, the latent variable, school belonging (Bel.), mediates the relationships made up of the different types of school climates $(\mathrm{Cs}=$ security, $\mathrm{Cr}=$ relational, $\mathrm{Cj}=$ justice $)$ in order to explain the three types of school engagement $(\mathrm{Cog}=$ cognitive, Aff $=$ affective, Beh = behavioral). Because our initial hypothetical model (Model 1) did not fit well according to the criteria mentioned above (see Table 1), we conducted a certain number of modifications to improve the fit of the model.

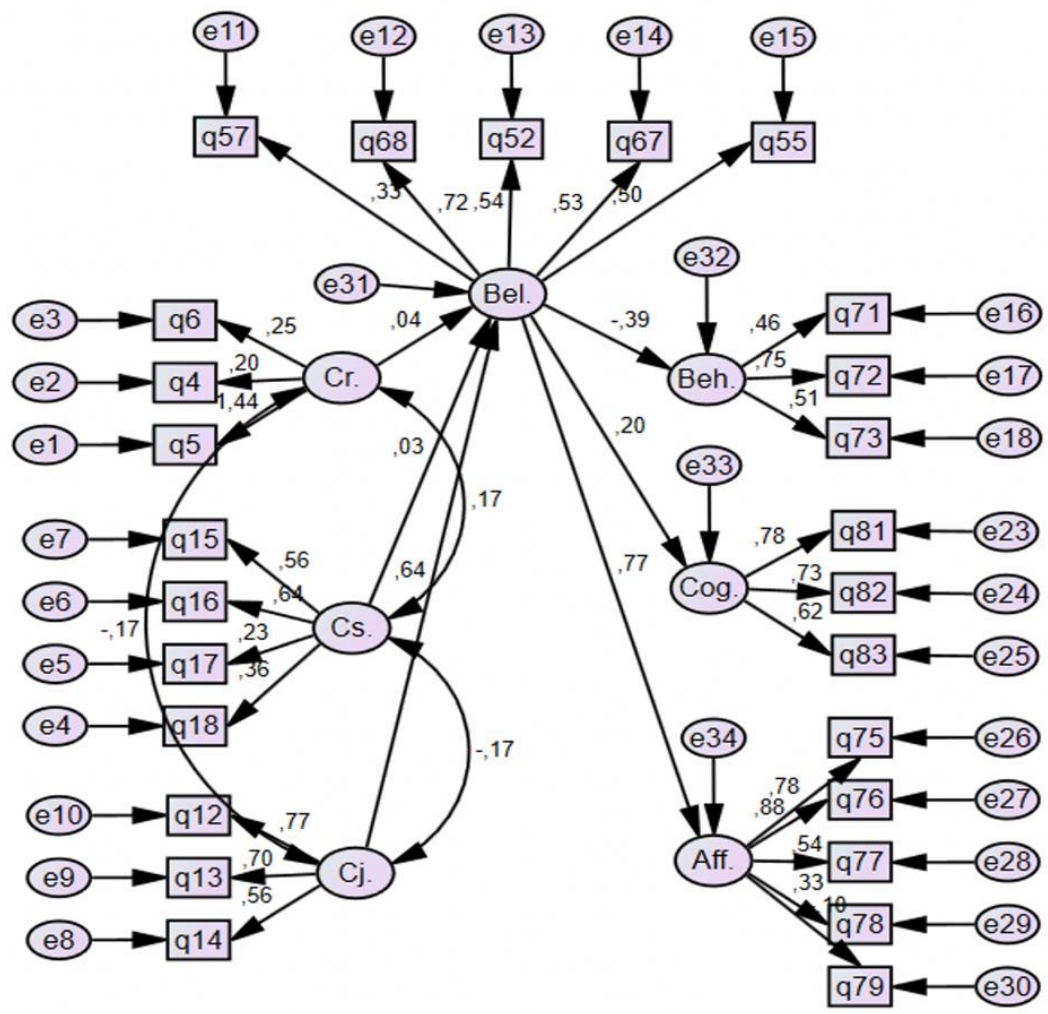

Figure 2: Hypothetical model (Model 1)

\subsubsection{Subsequent models}

Considering the modification indices, two links were removed (the relational climate and school belonging; the climate of security and school belonging) because they were not significant. In addition, in Model 2, and according to the modification indices, several error terms were correlated (17 and 18, 26 and 29, 11 and 12, 11 and 15). In model 2, the definitive model, the fit indices were all satisfactory (see Table 1). In the final model (Model 2), two links were removed between the two types of climates (relational and security) and school belonging; all the other links of Model 1 were preserved because they are significant. 


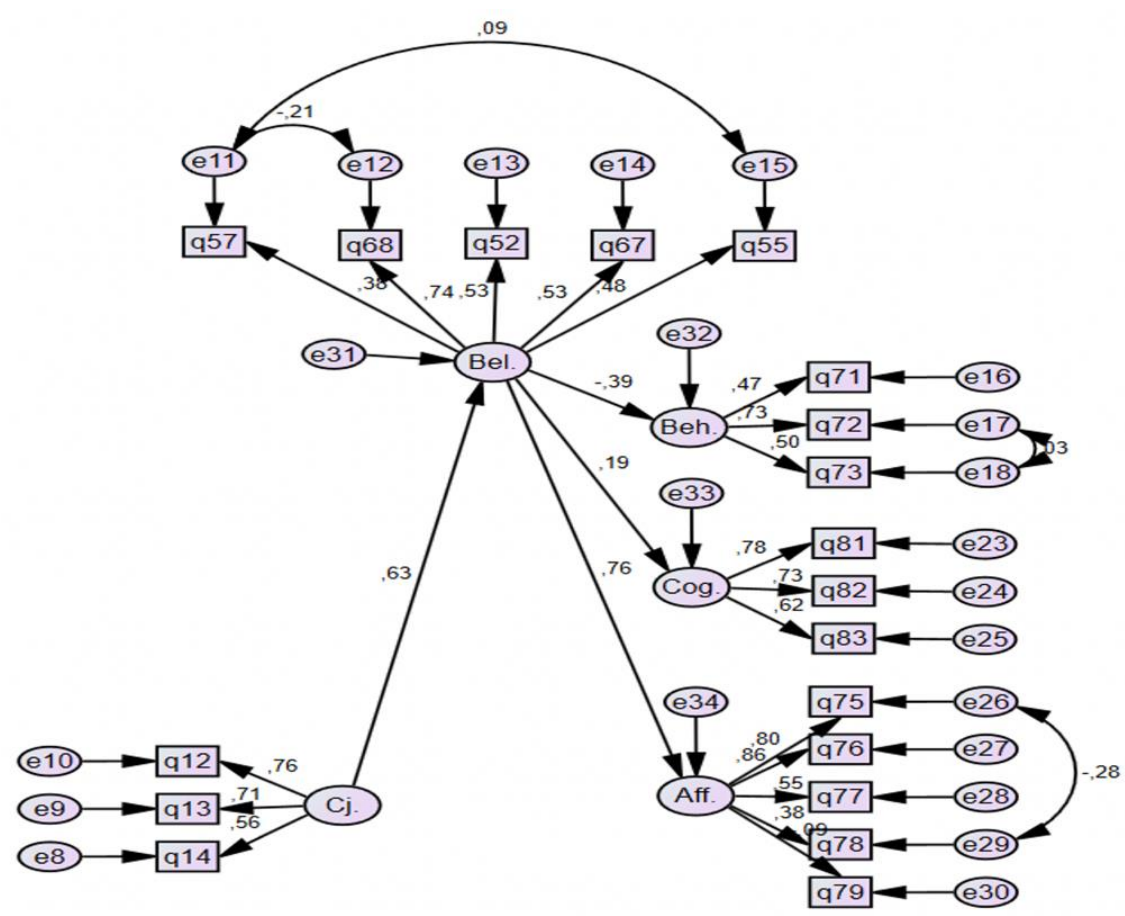

Figure 3. Final model (Model 2)

The standardized coefficients for all the relationships between the variables of Model 2 (final model) are shown in Figure 3. The final model (with the full sample) fitted the data better than the previous model according to the fit indices (see Table 1). Consequently, the final model was used to interpret the relationships between the variables. In the final model, school belonging was significantly associated with the three forms of school engagement. The strongest positive relationships in the final model are between school belonging and affective engagement, as well as between the climate of justice and school belonging.

Table 1: Results for models 1 and 2

\begin{tabular}{cccccc}
\hline Models & $\mathbf{X}^{\mathbf{2}}$ & df & CFI & TLI & RMSEA \\
\hline $\begin{array}{c}\text { Model 1 } \\
\text { (Full sample) }\end{array}$ & 396.36 & 290 & .91 & .90 & .039 \\
$\begin{array}{c}\text { Model 2 } \\
\text { (Full sample) }\end{array}$ & 207.37 & 144 & .94 & .93 & .042 \\
\hline
\end{tabular}

We then conducted an analysis to compare the fit of Model 2 (final model) in regard to gender (see table 2). When analyzed separately, both models had a borderline fit. 
Table 2. Results for model 2 (females and males, separately)

\begin{tabular}{cccccc}
\hline Models & $\mathbf{X}^{\mathbf{2}}$ & $\mathbf{d f}$ & $\mathbf{C F I}$ & TLI & RMSEA \\
\hline $\begin{array}{c}\text { Model 2 } \\
\text { (Females) }\end{array}$ & 187.973 & 144 & .92 & .91 & .047 \\
$\begin{array}{c}\text { Model 2 } \\
\text { (Males) }\end{array}$ & 193.528 & 144 & .89 & .87 & .059 \\
\hline
\end{tabular}

However, multigroup analysis determined that the final model could not be considered equal in regard to gender; the $\mathrm{X}^{2}$-difference value was statistically significant at a probability of less than $.05(p=.004)$. Based on these results, we concluded that one or more of the factor loadings are not operating equivalently across the two groups. We then explored where the differences between the two models (females and males) could be by constraining each path in light of a chi square different test (Byrne, 2016). Three relations did not show any difference in regard to gender (belonging and cognitive engagement, $p=.651$; belonging and affective engagement, $p=.620$; the climate of justice and belonging, $p=$ .800). The only significant difference in regard to gender was between school belonging and behavioral engagement $(p=.008)$. Hence, it allowed us to determine that the positive effect of school belonging on the three types of school engagement (cognitive, affective, and behavioral) was in fact significantly stronger for females than for males only for behavioral engagement (hypothesis $4)$.

\section{Discussion}

The objective of this study was to better understand the links between multiple dimensions of school climate (justice, relational, security), school belonging, and school engagement (cognitive, affective, behavioral), and to test these relationships for invariance across genders. Our hypotheses were based on the theoretical work of Janosz et al. (1998) as well as on many studies exploring academic motivation (Furrer \& Skinner, 2003; Gillen-O'Neel \& Fuligni, 2013; Goodenow, 1993a; Goodenow \& Grady, 1993), and other theorists who tried to sched light on many phenomena such as school perseverance, school failure, and academic achievement (Juvonen, 2006; Finn, 1989; Newmann et al., 1992; StAmand et al., 2020a; Wehlage et al., 1989). Our review of the literature led us to validate four hypotheses, which had not yet been the subject of empirical validation with high school students living in Morocco.

\subsection{Partial confirmation of hypothesis 1}

The first hypothesis indicated that the different types of school climates (justice, relational, security) have a positive effect on school belonging. This hypothesis was partially supported. Our results determined that, among the three climates, only the climate of justice had an effect on school belonging. This meaningful relationship can take root in the school's supervision system that effectively responds to behavioral issues, as well as the many acts of violence in the schools. Despite the difficulties encountered, this system can generate mutual commitment between young people, their parents, and education agents. This social contract, described and disseminated in a disciplinary framework, can 
reflect the values and the rules of the school. These can be combined with measures seen as strategies, leading students to make responsible choices. This supervision system can favor coherent interventions with regard to a respect for oneself, others and the environment. This system can promote a democratic environment guaranteeing justice and equity while contributing to school belonging (Janosz et al., 1998; Karakuş, 2017; Moliner García et al., 2016). The non-significant relationships between, on one side, the relational climate and the climate of security and, on the other side, school belonging, can be explained by the general context of our study. In a recent report on school violence conducted by United Nations Educational, Scientific and Cultural Organization (2019), it is clear that violence is still extremely present in schools in Morocco. The prevalence of bullying in schools reached $32.2 \%$. This means that almost one in three students have been the victim of bullying. With regard to children and adolescents, a total of $39.7 \%$ declared having been victims of fights. The figure is on the rise for boys $(53.3 \%)$, while for girls it represents only $24.6 \%$. These numbers are way higher than the ones we find in The Caribbean, Europe, Central America, South America, and North America, while being close to the ones we find in the Middle East, and sub-Saharan Africa (United Nations Educational, Scientific and Cultural Organization, 2019). These statistics may explain the poor climate of security and the difficulty for students to maintain quality social relationships with their peers at school. By extension, it can explain the non-significant relationships with the students' sense of school belonging.

\subsection{Confirmation of hypotheses 2 and 3}

As corollary to our second hypothesis, school belonging had a positive effect on the three types of school engagement (cognitive, affective, and behavioral). As demonstrated by St-Amand et al. (2020a), the positive emotions generated by the feeling of belonging can be an explanatory element of school engagement. Despite considering a so-called general variable measuring positive emotions, St-Amand et al. (2020a) did not take into account other contextual emotions that may explain these relationships. Researchers have documented in recent years the notion of "achievement emotions" which are defined "as emotions that are directly linked to achievement activities or achievement outcomes" (Pekrun, 2000; Pekrun et al., 2006, 2012). In this sense, it is possible that the feeling of belonging influences the achievement emotions of the students regarding the context where they take place (e.g., class-related, learning-related, and testrelated emotions). Pekrun et al. (2002) proposed four types of achievement emotions: (1) positive activating: enjoyment, hope, pride; (2) positive deactivating: relief; (3) negative activating: anger, anxiety, shame; and (4) negative deactivating: hopelessness, boredom. Pekrun et al. (2002) suggested that attending school, studying, or completing exams generates different emotions. In this context, one could assume that school belonging influences these achievement emotions to some degree, which in turn influences school engagement. Finally, the mediating role of school belonging in the relationships made up of the climate of justice and school engagement (hypothesis 3) can be explained through the very close relationship between school belonging and engagement. For the past thirty years, in fact, this close relationship has been 
theoretically and widely recognized (Anderman \& Freeman, 2004; Finn, 1989; Newmann et al., 1992; Wehlage et al., 1989; St-Amand et al., 2020a). With regard to the negative relationship between school belonging and behavioral engagement, one must take into account the items to better understand these relationships (e.g., during the last 12 months, did you miss school without a valid excuse? / in the last 12 months, did you miss a class while you were in school?). The items measuring behavioral engagement may explain these negative results, as it is possible that the more a student belongs, the less he or she will disturb the class and skip school. This negative relationship is therefore quite normal given the items measuring behavioral engagement.

\subsection{Partial confirmation of hypothesis 4}

The fourth hypothesis indicated that the positive effect of school belonging on the three types of school engagement (cognitive, affective, and behavioral) is stronger for females than for males. This hypothesis was partially supported by our results. It was only the case for behavioral engagement, which measured student engagement related to the norms and values of the code of life of the school (e.g., high level of attendance, anti-social behaviors). This result could be explained by the social developmental model which attempts to explain substance use and other antisocial behavior (Catalano \& Hawkins, 1996; Maddox \& Prinz, 2003). Indeed, during adolescence, peers are the most important influence. Opportunities for interacting with peers increase in adolescence and the level of parental supervision tends to decline, exposing young people to antisocial peers (Catalano \& Hawkins, 1996). Since boys are generally more exposed to antisocial peers and girls are less likely to be influenced by them (Geven et al., 2017; Haynie et al., 2014), it is conceivable that this affects the relationship between school belonging and behavioral engagement in regard to gender.

\section{Conclusion}

A growing body of research indicates that school climate is associated with, and can be predictive of, many students' outcomes. Meta-analyses demonstrated that school climate influences problem behaviors over time (Reaves et al., 2018), violence in school (Steffgen et al., 2013), and academic achievement (Karadağ et al., 2016). Besides, the Centers for Disease Control and Prevention (2009) and many researchers (Thapa et al., 2009) recommend that school climate should be used as a strategy to promote school belonging. That said, our results must be considered in the context of our study: relatively violent school environments in Morocco. The non-significant relationships between certain climates (the relational climate and the climate of security) and school belonging constitute an element which illustrates this reality. Thus, the United Nations Educational, Scientific and Cultural Organization (2019) introduced a certain number of recommendations with regard to the management of potentially violent school environments in Morocco that we believe is an excellent starting point: (1) to ensure that legislation is put in place to protect the rights of children; (2) to train and support teachers so that they can not only prevent violence and bullying in school but also respond to it; (3) to provide children with information and support so that they can report violence and seek help; and (4) to pay particular 
attention to children who are more vulnerable because of their race, ethnicity, disability, gender, or sexual orientation. As in all studies, this one has limitations and other research avenues that we would like to highlight. First, our sample is made up of students from only two schools. This situation prevents us from generalizing our results to the whole student population in Morocco to other regions of Morocco. Second, the internal consistency of some scales appeared a little bit low even if they met the requirements. This suggests the subsequent use of other scales that may have a stronger internal consistency. Third, our research design was limited to one time of measurement. Therefore, a longitudinal design would make it possible to analyze the relationships under study, target periods of greater risk during the school year, and prepare interventions adapted to this situation. Although we used a general measure of the climate of justice, it would have been possible to measure more precise elements relating to this climate, and the effect of distributive classroom justice, procedural classroom justice, and interactional classroom justice on school belonging (Berti et al., 2010).

\section{References}

Ahmadi, S., Hassani, M., \& Ahmadi, F. (2020). Student- and school-level factors related to school belongingness among high school students. International Journal of Adolescence and Youth, 25(1), 741-752. https://doi.org/10.1080/02673843.2020. 1730200

Allen, K., Kern, M. L., Vella-Brodrick, D., Hattie, J., \& Waters, L. (2018). What schools need to know about fostering school belonging: A meta-analysis. Educational Psychology Review, 30(1), 1-34. http:/ / dx.doi.org/10.1007/s10648-016-9389-8

Anderman, L. H., \& Freeman, T. M. (2004). Students' sense of belonging in school. In P. R. Pintrich \& M. L. Maehr (Eds.), Motivating students, improving schools: The legacy of Carol Midgley (Vol. 13, pp. 27-63). Elsevier.

Baumeister, R. F., \& Leary, M. R. (1995). The need to belong: Desire for interpersonal attachments as a fundamental human motivation. Psychological Bulletin, 117(3), 497-529. https://doi.org/10.1037/0033-2909.117.3.497

Bentler, P. M., \& Chou, C. P. (1987). Practical issues in structural modeling. Sociological Methods \& Research, 16(1), 78-117. https:// doi.org/10.1177/0049124187016001004

Berti, C., Molinari, L., \& Speltini, G. (2010). Classroom justice and psychological engagement: Students' and teachers' representations. Social psychology of education, 13(4), 541-556. _https:// doi.org/10.1007/s11218-010-9128-9

Booker, K. C. (2007). Likeness, comfort, and tolerance: Examining African American adolescents' sense of school belonging. The Urban Review: Issues and Ideas in Education, 39(3), 301-317. https://doi.org/10.1007/s11256-007-0053-y

Byrne, B. M. (2016). Structural Equation Modelling with AMOS: Basic Concepts, Applications, and Programming (3rd ed.). Routledge.

Catalano, R. F., \& Hawkins, J. D. (1996). The social development model: A theory of antisocial behavior. In J. D. Hawkins (Ed.), Delinquency and crime: Current theories (pp. 149-197). Springer-Verlag.

Connell, J. P., Spencer, M. B., \& Alber, J. L. (1994). Educational risk and resilience in African-American youth: Context, self, action, and outcomes in school. Child Development, 65(2), 493-506. https://doi.org/10.1111/j.1467-8624.1994.tb00765.x

Creemers, B. P. M., \& Kyriakides, L. (2008). The dynamics of educational effectiveness: A contribution to policy, practice and theory in contemporary schools. Routledge.

Crooks, C. V., Scott, K. L., Wolfe, D. A., Chiodo, D., \& Killip, S. (2007). Understanding the link between childhood maltreatment and violent delinquency: What do 
schools have to add? Child Maltreatment, 12(3), 269-280. https://doi.org/10.1177\%2F1077 559507301843

Centers for Disease Control and Prevention (2009). School Connectedness: Strategies for Increasing Protective Factors Among Youth. Atlanta, GA: U.S. Department of Health and Human Services.

Dimitrellou, E., \& Hurry, J. (2019). School belonging among young adolescents with SEMH and MLD: the link with their social relations and school inclusivity. European Journal of Special Needs Education,34(3), 312-326. http://dx.doi.org/10.1080/08856257.2018.1501965

Deci, E. L., Vallerand, R. J., Pelletier, L. G., \& Ryan, R. M. (1991). Motivation and education: The self-determination perspective. Educational Psychologist, 26(3-4), 325-346. https://doi.org/10.1080/00461520.1991.9653137

Demanet, J., \& Van Houtte, M. (2012). School belonging and school misconduct: The differing role of teacher and peer attachment. Journal of Youth and Adolescence, 41(4), 499-514. https://doi.org/10.1007/s10964-011-9674-2

Einberg, E.-L., Lidell, E., \& Clausson, E. K. (2015). Awareness of demands and unfairness and the importance of connectedness and security: Teenage girls' lived experiences of their everyday lives. International Journal of Qualitative Studies on Health and Well-being, 10(1), 1-12. https://doi.org/10.3402/qhw.v10.27653

Faircloth, B. S., \& Hamm, J. V. (2005). Sense of belonging among high school students representing 4 ethnic groups. Journal of Youth and Adolescence, 34(4), 293-309. https://doi.org/10.1007/s10964-005-5752-7

Finn, J. D. (1989). Withdrawing from school. Review of Educational Research, 59(2), 117-142. https://doi.org/10.3102\%2F00346543059002117

Fredricks, J. A., Blumenfeld, P. C., \& Paris, A. H. (2004). School engagement: Potential of the concept, state of the evidence. Review of Educational Research, 74(1), 59-109. https://doi.org/10.3102\%2F00346543074001059

Furrer, C., \& Skinner, E. (2003). Sense of relatedness as a factor in children's academic engagement and performance. Journal of Educational Psychology, 95(1), 148-162. https://doi.org/10.1037/0022-0663.95.1.148

Geven, S., Jonsson, J. O., \& van Tubergen, F. (2017). Gender differences in resistance to schooling: The role of dynamic peer-influence and selection processes. Journal of Youth and Adolescence, 46(12), 2421-2445. https://doi.org/10.1007/s10964-0170696-2

Gillen-O'Neel, C., \& Fuligni, A. (2013). A longitudinal study of school belonging and academic motivation across high school. Child development, 84(2), 678-692. https:// doi.org/10.1111/j.1467-8624.2012.01862.x

Goodenow, C. (1993a). Classroom belonging among early adolescent students: Relationships to motivation and achievement. The Journal of Early Adolescence, 13(1), 21-43. https://doi.org/10.1177\%2F0272431693013001002

Goodenow, C. (1993b). The psychological sense of school membership among adolescents: Scale development and educational correlates. Psychology in the Schools, 30(1), 79-90. https://doi.org/10.1002/15206807(199301)30:1\%3C79::AID-PITS231 0300113\%3E3.0.CO;2-X

Goodenow, C., \& Grady, K. E. (1993). The relationship of school belonging and friends' values to academic motivation among urban adolescent students. The Journal of Experimental Education, 62 60-71. https:// psycnet.apa.org/doi/10.1080/00220973.1993.9943831

Hagborg, W. J. (1998). An investigation of a brief measure of school membership. Adolescence, 33(130), 461-468. 
Haynie, D. L., Doogan, N. J., \& Soller, B. (2014). Gender, friendship networks, and delinquency: A dynamic network approach. Criminology, 52(4), 688-722. https:// doi.org/10.1111/1745-9125.12052

Hu, L., \& Bentler, P. M. (1999). Cutoff criteria for fit indexes in covariance structure analysis: Conventional criteria versus new alternatives. Structural Equation $\begin{array}{lllll}\text { Modeling: A } & \text { Multidisciplinary Journal, }\end{array}$ https://doi.org/10.1080/10705519909540118

Ibrahim, A., \& El Zaatari, W. (2020). The teacher-student relationship and adolescents' sense of school belonging. International Journal of Adolescence and Youth, 25(1), 382-395. http://dx.doi.org/10.1080/02673843.2019.1660998

Isakson, K., \& Jarvis, P. (1999). The adjustment of adolescents during the transition into high school: A short-term longitudinal study. Journal of Youth and Adolescence, 28(1), 1-26. https://doi.org/10.1023/ A:1021616407189

Janosz, M., \& Bouthillier, C. (2007). Rapport de validation du Questionnaire sur l'environnement socioéducatif des écoles secondaires (QES-secondaire). http://www.gres.umontreal.ca/download/Rapport_validation_QESsecondaire.pdf

Janosz, M., Georges, P., \& Parent, P. (1998). L'environnement socioéducatif à l'école secondaire : un modèle théorique pour guider l'évaluation du milieu. Revue Canadienne de Psychoéducation, 27(2), 285-306.

Juvonen, J. (2006). Sense of belonging, social bonds, and school functioning. In P. A. Alexander \& P. H. Winne (Eds.), Handbook of Educational Psychology (pp. 655-674). Erlbaum.

Karadă̆, E., İşçi, S., Öztekin, Ö., \& Anar, S. (2016). The relationship between school climate and students' academic achievement: A meta-analysis study. İnönü University Journal of the Faculty of Education, 17(2), 107-122. https://doi.org/10.17679/iuefd.17294446

Karakus, M. (2017). An investigation of students' perceptions about democratic school climate and sense of community in school. Universal Journal of Educational Research, 5(5), 787-790. https://doi.org/10.13189/ujer.2017.050511

Kline, R. B. (2016). Principals and practice of structural equation modeling (4th ed.). The Guilford Press.

Korpershoek, H., Canrinus, E. T., Fokkens-Bruinsma, M., \& de Boer, H. (2020). The relationships between school belonging and students' motivational, socialemotional, behavioural, and academic outcomes in secondary education: A meta-analytic review. Research Papers in Education, 35(6), 641-680. https://doi.org/10.1080/02671522.2019.1615116

Kuang, X., Mok, M. M. C., Chiu, M. M., \& Zhu, J. (2019). Sense of school belonging: Psychometric properties and differences across gender, grades, and East Asian societies. PsyCh Journal, 8(4), 449-464. https://doi.org/10.1002/pchj.275

Langevin, L. (1999). L'abandon scolaire : on ne naît pas décrocheur. Logiques.

London, R., \& Ingram, D. (2018). Social isolation in middle school. School Community Journal, 28(1), 107-127.

Lewis, K. M., Sullivan, C. M., \& Bybee, D. (2006). An experimental evaluation of a school-based emancipatory intervention to promote African American wellbeing and youth leadership. Journal of Black Psychology, 32(1), 3-28. https:// doi.org/10.1177\% 2F0095798405283229

MacCallum, R. C., Browne, M. W., \& Sugawara, H. M. (1996). Power analysis and determination of sample size for covariance structure modeling. Psychological Methods, 1(2), 130-149. https:// doi.org/10.1037/1082-989x.1.2.130 
Maddox, S. J., \& Prinz, R. J. (2003). School bonding in children and adolescents: Conceptualization, assessment, and associated variables. Clinical Child and Family Psychology review, 6(1), 31-49. https://doi.org/10.1023/A:1022214022478

Maslow, A. (1962). Towards a psychology of need. Van Nostrand.

Maslow, A. (1970). Motivation and personality. Harper and Row.

McGraw, K., Moore, S., Fuller, A., \& Bates, G. (2008). Family, peer and school connectedness in final year secondary school students. Australian Psychologist, 43(1), 27-37. https://doi.org/10.1080/00050060701668637

McMillan, D. W., \& Chavis, D. M. (1986). Sense of community: A definition and theory. Journal of Community Psychology, 14(1), 6-23. https://doi.org/10.1002/1520-6629(198601)14:1\%3C6::AIDJCOP2290140103\%3E3.0.CO;2-I

Molinari, L., Speltini, G., \& Passini, S. (2013). Do perceptions of being treated fairly increase students' outcomes? Teacher-student interactions and classroom justice in Italian adolescents. Educational Research and Evaluation, 19(1), 58-76. https:// doi.org/10.1080/13803611.2012.748254

Moliner García, O., Traver Martí, J. A., Ruiz Bernardo, M. P., \& Segarra Arnau, T. (2016). Strategies influencing democratization processes in schools: a theoretical approach. Revista electrónica de investigación educativa, 18(2), 116-129.

Newmann, F. M., Wehlage, G. G., \& Lamborn, S. D. (1992). The significance and sources of student engagement. In F. M. Newmann (Ed.), Student engagement and achievement in American secondary schools (pp. 11-39). Teachers College Press.

Osterman, K. F. (2000). Students' need for belonging in the school community. Review of Educational Research, 70(3), 323-367. https://doi.org/10.3102\%2F0034654307000 3323

Pekrun, R. (2000). A social cognitive, control-value theory of achievement emotions. In J. Heckhausen (Ed.), Advances in psychology. Motivational psychology of human development: Developing motivation and motivating development. Elsevier. https://psycnet.apa.org/doi/10.1016/S0166-4115(00)80010-2

Pekrun, R., Elliot, A. J., \& Maier, M. A. (2006). Achievement goals and discrete achievement emotions: A theoretical model and prospective test. Journal of Educational Psychology, 98(3), 583-597. https:// psycnet.apa.org/doi/10.1037/0022-0663.98.3.583

Pekrun, R., Goetz, T., Titz, W., \& Perry, R. P. (2002). Academic emotions in students' selfregulated learning and achievement: A program of quantitative and qualitative $\begin{array}{llll}\text { research. Educational } & \text { Psychologist, 37(2), }\end{array}$ https://doi.org/10.1207/S15326985EP3702_4

Pekrun, R., \& Linnenbrink-Garcia, L. (2012). Academic emotions and student engagement. In S. L. Christenson, A. L. Reschly, \& C. Wylie (Eds.), Handbook of research on student engagement (pp. 259-282). Springer. https://doi.org/10.1007/978-1-4614-2018-7_12

Perry, J. L., Nicholls, A. R., Clough, P. J., \& Crust, L. (2015). Assessing model fit: Caveats and recommendations for confirmatory factor analysis and exploratory structural equation modeling. Measurement in Physical Education and Exercise Science, 19(1), 12-21. https://doi.org/10.1080/1091367x.2014.952370

Peter, F., \& Dalbert, C. (2010). Do my teachers treat me justly? Implications of students' justice experience for class climate experience. Contemporary Educational Psychology, 35(4), 297-305. https://doi.org/10.1016/j.cedpsych.2010.06.001

Reaves, S., McMahon, S. D., Duffy, S. N., \& Ruiz, L. (2018). The test of time: A metaanalytic review of the relation between school climate and problem 
behavior. Aggression and Violent Behavior, 39, 100-108. http://dx.doi.org/10.1016/j.avb.2018.01.006

Resh, N., \& Sabbagh, C. (2014). Justice, belonging and trust among Israeli middle school students. British Educational Research Journal, 40(6), 1036-1056. https://doi.org/10.1002/berj.3129

Roeser, R. W., Midgley, C., \& Urdan, T. C. (1996). Perceptions of the school psychological environment and early adolescents' psychological and behavioral functioning in school: The mediating role of goals and belonging. Journal of Educational Psychology, 88(3), 408-422. https://psycnet.apa.org/doi/10.1037/00220663.88.3.408

Slaten, C. D., Ferguson, J. K., Allen, K. A., Brodrick, D. V., \& Waters, L. (2016). School belonging: A review of the history, current trends, and future directions. The Educational and Developmental Psychologist, 33(1), 1-15. http://dx.doi.org/10.1017/edp.2016.6

Smith J., Moreau, D., Paquin, St-Amand, J., \& Chouinard, R. (2020). The evolution of motivation to learn in the context of the transition to secondary school: Developmental trajectories and relational determinants. The International Journal of Pedagogy and Curriculum, 27(2), 17-37. https://doi.org/10.18848/2327-7963/CGP/v27i02/17-37

St-Amand, J., Boily, R., Bowen, F., Smith, J., Janosz, M., \& Verner-Filion, J. (2020b). The development of the French version of the Psychological Sense of School Membership (PSSM) questionnaire: An analysis of its structure, properties and potential for research with at-risk students. Interdisciplinary Education and Psychology, 2(3), 3.

St-Amand, J., J., Bowen, F., Bulut, O., Cormier, D., Janosz, M., \& Girard, S. (2020a). Le sentiment d'appartenance à l'école: validation d'un modèle théorique prédisant l'engagement et le rendement scolaire en mathématiques d'élèves du secondaire [School belonging: Validation of a theoretical model that predicts school engagement and academic achievement in mathematics ]. Formation et profession, 28(2), 89-105. https:// doi.org/10.18162/ fp.2020.530

St-Amand, J. (2018). An examination of teachers' classroom management: Do gender stereotypes matter in student-teacher relations? The Online Journal of New Horizons in Education, 8(3), 1-9.

St-Amand, J., Bowen, F., \& Lin, T. W. J. (2017a). Le sentiment d'appartenance à l'école: une analyse conceptuelle [School belonging: A conceptual analysis]. Canadian Journal of Education, 40(1), 1-32. https://www.jstor.org/stable/90002333

St-Amand, J., Girard, S., \& Smith, J. (2017b). Sense of belonging at school: Defining attributes, determinants, and sustaining strategies. IAFOR Journal of Education, 5(2), 105-119. https://doi.org/10.22492/ije.5.2.05

Singh, K., Chang, M., \& Dika, S. (2010). Ethnicity, self-concept, and school belonging: Effects on school engagement. Educational Research for Policy and Practice, 9(3), 159-175. http://dx.doi.org/10.1007/s10671-010-9087-0

Singh, K., Chang, M., \& Dika, S. (2008). School engagement and school Learning: Ethnicity, self-concept, and school belonging. International Journal of Learning, 15(2). http://dx.doi.org/10.18848/1447-9494/CGP/v15i02/45627

Steffgen, G., Recchia, S., \& Viechtbauer, W. (2013). The link between school climate and violence in school: A meta-analytic review. Aggression and violent behavior, 18(2), 300-309. http://dx.doi.org/10.1016/j.avb.2012.12.001

Tabachnick, B. G., \& Fidell, L. S. (2013). Using multivariate statistics (6th ed.). Pearson. 
Thapa, A., Cohen, J., Guffey, S., \& Higgins-D'Alessandro, A. (2013). A review of school climate research. Review of educational research, 83(3), 357-385. http://dx.doi.org/10.3102/0034654313483907

Tyler, T. R. \& Blader, S. L. (2000) Cooperation in groups: Procedural justice, social identity, and behavioral engagement. Psychology Press.

United Nations Educational, Scientific and Cultural Organization (UNESCO) (2019). Behind the numbers: Ending school violence and bullying. UNESCO.

Uwah, C. J., McMahon, H. G., \& Furlow, C. F. (2008). School belonging, educational aspirations, and academic self-efficacy among African American male high school students: Implications for school counselors. Professional School Counseling, 11(5), 296-305. https:/ / doi.org/10.1177\%2F2156759X0801100503

van Gijn-Grosvenor, E. L., \& Huisman, P. (2020). A sense of belonging among Australian university students. Higher Education Research \& Development, 39(2), 376-389. https://doi.org/10.1080/07294360.2019.1666256

Walker, L., \& Avant, K. C. (2011). Strategies for theory construction in nursing (5th ed.). Prentice Hall.

Wehlage, G. G., Rutter, R. A., Smith, A. G., Lesko, N., \& Fernandez, R. R. (1989). Reducing the risk: Schools as communities of support. Falmer Press.

Williams, L. J., \& Downing, J. E. (1998). Membership and belonging in inclusive classrooms: What do middle school students have to say? Research and Practice for Persons with Severe Disabilities, 23(2), 98-110. https:// doi.org/10.2511\%2Frpsd .23 .2 .98 